\title{
Erratum to: Haloperidol Use Among Elderly Patients Undergoing Surgery: A Retrospective 1-Year Study in a Hospital Population
}

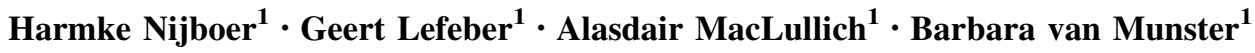

Published online: 11 April 2016

(C) The Author(s) 2016. This article is published with open access at Springerlink.com

\section{Erratum to: Drugs - Real World Outcomes (2016) 3:83-88 DOI 10.1007/s40801-016-0060-y}

An Online First version of this article was made available online at http://link.springer.com/journal/40801/onlineFirst/ page/1 on 3 March 2016. An error was subsequently identified in the article, and the following correction should be noted:

Page 1, author listing: The name of the third author, which previously read:

"Alidair McLullich"

should read:

"Alasdair MacLullich"

Page 5, Conflict of interest: The name of the first author, which previously read:

"Prof A McLullich"

should read:

"Prof A MacLullich".

\begin{abstract}
Open Access This article is distributed under the terms of the Creative Commons Attribution 4.0 International License (http:// creativecommons.org/licenses/by/4.0/), which permits unrestricted use, distribution, and reproduction in any medium, provided you give appropriate credit to the original author(s) and the source, provide a link to the Creative Commons license, and indicate if changes were made.
\end{abstract}

The online version of the original article can be found under doi:10.1007/s40801-016-0060-y.

Harmke Nijboer

harmke.nijboer@catharinaziekenhuis.nl

1 Catharina Hospital, Eindhoven, Brabant, The Netherlands 